\title{
Combination of Curcumin from Curcuma longa and Procyanidin from Tamarindus indica in Inhibiting Cyclooxygenases for Primary Dysmenorrhea Therapy: In silico study
}

\author{
Gabriella Chandrakirana Krisnamurti ${ }^{1}$ (D), Yohanes Bare ${ }^{2}$ (D), Mohamad Amin ${ }^{3}$ (D), \\ Cicilia Novi Primiani 3,* (D)
}

1 Biotechnology Program, School of Bioresources and Technology, King Mongkut's University of Technology Thonburi, 10150 Bang Khun Thian, Bangkok, Thailand; gabriella.chandrakirana@mail.kmutt.ac.th;

2 Biology Education Study Program, Faculty of Teaching and Training Education, Nusa Nipa University, 86111, Sikka, Indonesia; bareyohanes@gmail.com;

3 Department of Biology, Faculty of Mathematics and Science, Universitas Negeri Malang, Malang, East Java, Indonesia; mohamad.amin.fmipa@um.ac.id;

4 Biology Education, Faculty of Teacher Training and Education, PGRI Madiun University, Madiun, East Java, Indonesia; primiani@unipma.ac.id;

* Correspondence: primiani@unipma.ac.id;

Received: 11.05.2020; Revised: 10.06.2020; Accepted: 12.06.2020; Published: 17.06.2020

\begin{abstract}
Turmeric (Curcuma longa) and Tamarind (Tamarindus indica) are known for the antiinflammatory and antioxidant activity. The major bioactive compound found in turmeric is curcumin, and tamarind is procyanidin. Both compounds could reduce prostaglandin concentration, leading to the reduction of primary dysmenorrhea by inhibiting COXs. This study aims to identify the interaction of tamarind and turmeric bioactive compounds as single isolated compound and complex compounds to COXs using in silico as a model study. Proteins and bioactive compounds were obtained from PDB database and Pubchem, respectively. Both proteins and ligands will be prepared using Discovery Studio Client 3.5 and PyRx 0.8. The interaction will be performed by docking using Autodock Vina in PyRx 0.8. It showed that turmeric and tamarind bioactive compounds in single isolated form have potency in inhibiting COX-1/COX-2, and both ligands bind to the catalytic site of proteins. Binding sites are surrounding the binding site of the natural substrate with an efficient binding affinity. In the complex form of turmeric-tamarind, the binding affinity is not as efficient as single compounds. However, its complex form of both compounds provides strong inhibition. This study suggested that complex forms of curcumin and procyanidin can reduce prostaglandin concentration and stabilize protein-ligand interaction lead to healing dysmenorrhea.
\end{abstract}

Keywords: Curcumin; Dysmenorrhea; COXs; In-silico; Procyanidin.

(C) 2020 by the authors. This article is an open-access article distributed under the terms and conditions of the Creative Commons Attribution (CC BY) license (https://creativecommons.org/licenses/by/4.0/).

\section{Introduction}

Drug treatment and therapy named traditional herbs currently developed from natural bioactive compounds. Traditional herbs widely used by the public and reported could treat the health-related problem, such as inflammation. Tamarind (Tamarindus indica) and turmeric (Curcuma longa) are traditional herbs cultivated in Indonesia and known for the potential. Both traditional herbs can treat health problems such as pain, dysenteric, fever, coughs, rheumatism, diarrhea, has anti-bacterial, anti-inflammatory, antioxidant properties, chemopreventive, and 
chemotherapeutic activity [1-4]. Traditionally, consuming traditional herbs as a crude material and combining some herbs assumed has a better effect than an isolated compound. It consists of various bioactive compounds, improving physiological activity, and provide better effects because of the interaction of each compound in the complex then lead to less side effect [5-9].

Primary dysmenorrhea is an occurrence in ovulating women and noticed with intense pain menstrual cramps. It related to endometriosis spastic uterine hypercontractility. Pain in primary dysmenorrhea is related with a high concentration of $\mathrm{PGE}_{2}$ and $\mathrm{PGF}_{2 \alpha}$. Pain could be reduced by cyclooxygenases (COX) enzyme inhibitor drugs, such as ibuprofen and mefenamic acid [10-13]. COX is a protein that responds to inflammation activity. COX-1 enzyme modulates the initial phase of acute inflammation, while COX-2 enzyme is one essential factor of inflammation $[14,15]$. The activity of COXs leads to prostaglandin synthesis and causing primary dysmenorrhea. According to that issue, natural compounds are identified to develop drugs to inhibit COXs enzyme activity [14,16]. Some study also develops treatment and therapy by using bioactive compounds, such as tamarind and turmeric. A combination of those herbs was believed to give a significant effect in treatment and therapy $(3,17,18)$.

According to the previous research, procyanidins, catechins, taxifolin, apigenin, luteolin, and naringenin are specific flavonoids of $T$. indica that has been isolated and identified. Flavonoids could be 5-lipoxygenase enzyme inhibitor, lead to low inflammation. Among flavonoids in T. indica, procyanidins build up $60 \%$ of the phytochemicals and known for the anti-inflammatory and analgesic activity [19-22]. Moreover, $C$. longa is a well-known traditional herb and provides many biological activities, especially anti-inflammatory activity. This herb plays a vital role in reducing inflammation. It is able to prevent biosynthesis of inflammatory prostaglandin from arachidonic acid. Curcumin, major bioactive compounds of turmeric, can interact with LOX, COX, phospholipase, TNF, and other pro-inflammatory proteins lead to reducing inflammatory activity [1,23-25].

Treatment using medicinal plants is treatment using all parts of a plant or plant mixture. The mixture of plant extracts has greater activity than isolated constituents [26]. In Indonesia, tamarind and turmeric are often consumed together, named kunir asem to reduce menstruation pain and provide physiological effects [27]. It has been widely consumed, but the molecular interaction of proteins and ligands still not well-studied. This study aims to identify the interaction of tamarind and turmeric bioactive compounds as single isolated compound and complex compounds to COX-1 and COX-2 by using in silico for model study.

\section{Materials and Methods}

\subsection{Proteins and Ligands Preparation.}

Protein structure of COX-1 (1EQG) and COX-2 (6COX) were retrieved from PDB database and were prepared using Discovery Studio Client 3.5 by removing ligands and water molecules. Pubchem databases were used to obtain ligands structure, curcumin (CID 44559528), and procyanidin (CID 31211). Ligands structures were prepared using PyRx 0.8 by minimizing the energy and converting it to PDB extension. 


\subsection{Docking.}

Proteins and ligands were docked by Autodock Vina in PyRx 0.8. Docking results were analyzed using Discovery Studio Client 3.5 (http://www.3dsbiovia.com). The analysis based on two dimensions and three dimensions visualization, also the compilation table.

\section{Results and Discussion}

\subsection{Interaction of Single Compounds (Curcumin and Procyanidin) to COXs Protein.}

This study provides a compilation of proteins-ligands interactions (Table 1). In the binding energy, the lowest energy suggested the most efficient interaction. As shown in table 1 , both bioactive compounds can interact strongly with COXs isomers. It indicates that procyanidin and curcumin could be $\mathrm{COX}$ inhibitors. Interaction of $\mathrm{COX}-1$ with curcumin (Figure 1a, Table 1) posed a strong binding. It is shown in the figure that the binding is surrounding catalytic sites, the binding site of arachidonic acid with COX-2 (Tyr-385), and dominated by hydrogen bond indicated the strong binding. As for the procyanidin with COX1 binding (Figure 1b, Table 1), it also mostly consists of hydrogen and hydrophobic interaction. The interaction of ligands with COX-1 is shown for the potential. Interestingly, interactions of ligands with COX-2 showed some similarities with COX-1. It forms binding within the specified sites, which predicted that tamarind and turmeric could work effectively both in COX-1 and COX-2. As shown in figure 1c, interactions formed in the active sites which placed for protein synthesis of the enzyme. Although this is curcumin, the interactions are similar to COX-1 and procyanidin binding. The interactions are closely formed within Tyr385 and supposed could inhibit COX-2 activity effectively. However, COX-2 and procyanidin binding are likely the same with COX-2 and curcumin binding. From this result, it suggested that the binding of tamarind and turmeric are specific to COX-2.

The binding of curcumin and procyanidin both occur nearly with Tyr-385 and Ser-530. The Tyr-385 and Ser-530 are responsible for prostaglandin synthesis [28]. Binding near those amino acid residues might lead to blocking prostaglandin synthesis. Interestingly, the interactions of curcumin and procyanidin that occur in COX-1 and COX-2 had bonding that can modulate the efficiency of ligand binding [29,30]. It has hydrogen bonds and hydrophobic, bonds which make a strong binding and stabilize the protein-ligand binding, respectively [31]. The interaction of procyanidin-curcumin to COXs also posed an electrostatic bond, improving ligand efficiency $[29,32]$.

Table 1. Interaction of Curcumin and Procyanidin to COX-1 and COX-2

\begin{tabular}{|c|c|c|c|c|c|c|}
\hline Protein & Ligand & Name & Category & $\begin{array}{c}\text { From } \\
\text { chemistry }\end{array}$ & $\begin{array}{c}\text { To } \\
\text { chemistry }\end{array}$ & $\begin{array}{c}\text { Binding } \\
\text { affinity } \\
(\mathrm{kcal} / \mathrm{mol})\end{array}$ \\
\hline \multirow{7}{*}{$\mathrm{COX}-1$} & \multirow{5}{*}{ Curcumin } & A:GLY225:N - :LIG1:O & $\begin{array}{l}\text { Hydrogen } \\
\text { Bond }\end{array}$ & H-Donor & H-Acceptor & \multirow{4}{*}{$-7,6$} \\
\hline & & $\begin{array}{c}\text { A:ARG374:NH2 - } \\
\text { :LIG1:0 }\end{array}$ & $\begin{array}{l}\text { Hydrogen } \\
\text { Bond }\end{array}$ & H-Donor & H-Acceptor & \\
\hline & & $\begin{array}{c}\text { B:ARG374:NH2 - } \\
\text { :LIG1:O }\end{array}$ & $\begin{array}{l}\text { Hydrogen } \\
\text { Bond }\end{array}$ & H-Donor & H-Acceptor & \\
\hline & & :LIG1:C - A:PHE142:O & $\begin{array}{l}\text { Hydrogen } \\
\text { Bond }\end{array}$ & H-Donor & H-Acceptor & \\
\hline & & B:VAL145:CG2 - :LIG1 & Hydrophobic & $\mathrm{C}-\mathrm{H}$ & Pi-Orbitals & \multirow{3}{*}{-10} \\
\hline & \multirow{2}{*}{ Procyanidin } & :LIG1:H - :LIG1:O & $\begin{array}{l}\text { Hydrogen } \\
\text { Bond }\end{array}$ & H-Donor & H-Acceptor & \\
\hline & & :LIG1:H - B:ASN375:O & $\begin{array}{l}\text { Hydrogen } \\
\text { Bond }\end{array}$ & H-Donor & H-Acceptor & \\
\hline
\end{tabular}




\begin{tabular}{|c|c|c|c|c|c|c|}
\hline Protein & Ligand & Name & Category & $\begin{array}{c}\text { From } \\
\text { chemistry }\end{array}$ & $\begin{array}{c}\text { To } \\
\text { chemistry }\end{array}$ & $\begin{array}{c}\text { Binding } \\
\text { affinity } \\
\text { (kcal/mol) }\end{array}$ \\
\hline & & :LIG1:H - A:GLY225:O & $\begin{array}{l}\text { Hydrogen } \\
\text { Bond }\end{array}$ & H-Donor & H-Acceptor & \\
\hline & & :LIG1:C - A:SER143:O & $\begin{array}{l}\text { Hydrogen } \\
\text { Bond }\end{array}$ & H-Donor & H-Acceptor & \\
\hline & & B:ARG374:NH2 - :LIG1 & Electrostatic & Positive & Pi-Orbitals & \\
\hline & & B:ARG374:NH2 - :LIG1 & Electrostatic & Positive & Pi-Orbitals & \\
\hline & & :LIG1 - :LIG1 & Hydrophobic & Pi-Orbitals & Pi-Orbitals & \\
\hline & & A:VAL145 - :LIG1 & Hydrophobic & Alkyl & Alkyl & \\
\hline & & B:VAL145 - :LIG1 & Hydrophobic & Alkyl & Alkyl & \\
\hline & & :LIG1 - B:VAL145 & Hydrophobic & Pi-Orbitals & Alkyl & \\
\hline & & :LIG1 - B:VAL145 & Hydrophobic & Pi-Orbitals & Alkyl & \\
\hline & & $\begin{array}{c}\text { :LIG1:H - } \\
\text { A:ARG374:NH2 } \\
\end{array}$ & Unfavorable & H-Donor & H-Donor & \\
\hline & & $\begin{array}{c}\text { :LIG1:H - } \\
\text { A:ARG376:NH1 } \\
\end{array}$ & Unfavorable & H-Donor & H-Donor & \multirow{9}{*}{$-7,7$} \\
\hline \multirow{20}{*}{ COX-2 } & \multirow{8}{*}{ Curcumin } & A:ASN375:N - :LIG1:O & $\begin{array}{l}\text { Hydrogen } \\
\text { Bond }\end{array}$ & H-Donor & H-Acceptor & \\
\hline & & B:ASN375:N - :LIG1:O & $\begin{array}{l}\text { Hydrogen } \\
\text { Bond }\end{array}$ & H-Donor & H-Acceptor & \\
\hline & & :LIG1:C - A:SER143:O & $\begin{array}{l}\text { Hydrogen } \\
\text { Bond }\end{array}$ & H-Donor & H-Acceptor & \\
\hline & & $\begin{array}{c}\text { A:ARG376:CD - } \\
\text { :LIG1:0 }\end{array}$ & $\begin{array}{l}\text { Hydrogen } \\
\text { Bond }\end{array}$ & H-Donor & H-Acceptor & \\
\hline & & :LIG1:C - :LIG1 & Hydrophobic & $\mathrm{C}-\mathrm{H}$ & Pi-Orbitals & \\
\hline & & :LIG1 - :LIG1 & Hydrophobic & Pi-Orbitals & Pi-Orbitals & \\
\hline & & :LIG1 - A:LEU145 & Hydrophobic & Pi-Orbitals & Alkyl & \\
\hline & & :LIG1 - B:LEU145 & Hydrophobic & Pi-Orbitals & Alkyl & \\
\hline & \multirow{12}{*}{ Procyanidin } & :LIG1:H - B:GLY225:O & $\begin{array}{l}\text { Hydrogen } \\
\text { Bond }\end{array}$ & H-Donor & H-Acceptor & \multirow{12}{*}{$-9,7$} \\
\hline & & :LIG1:H - B:GLY536:O & $\begin{array}{l}\text { Hydrogen } \\
\text { Bond }\end{array}$ & H-Donor & H-Acceptor & \\
\hline & & :LIG1:H - B:SER143:O & $\begin{array}{l}\text { Hydrogen } \\
\text { Bond }\end{array}$ & H-Donor & H-Acceptor & \\
\hline & & B:ASN375:N - :LIG1:O & $\begin{array}{l}\text { Hydrogen } \\
\text { Bond }\end{array}$ & H-Donor & H-Acceptor & \\
\hline & & $\begin{array}{c}\text { B:ARG376:CD - } \\
\text { :LIG1:O } \\
\end{array}$ & $\begin{array}{l}\text { Hydrogen } \\
\text { Bond }\end{array}$ & H-Donor & H-Acceptor & \\
\hline & & B:ARG376:NH1 - :LIG1 & Electrostatic & Positive & Pi-Orbitals & \\
\hline & & :LIG1 - A:PHE142 & Hydrophobic & Pi-Orbitals & Pi-Orbitals & \\
\hline & & A:LEU145 - :LIG1 & Hydrophobic & Alkyl & Alkyl & \\
\hline & & :LIG1 - A:LEU145 & Hydrophobic & Pi-Orbitals & Alkyl & \\
\hline & & :LIG1 - B:LEU145 & Hydrophobic & Pi-Orbitals & Alkyl & \\
\hline & & :LIG1 - A:LEU145 & Hydrophobic & Pi-Orbitals & Alkyl & \\
\hline & & :LIG1 - B:PRO538 & Hydrophobic & Pi-Orbitals & Alkyl & \\
\hline
\end{tabular}

Note: Bold is an acceptor

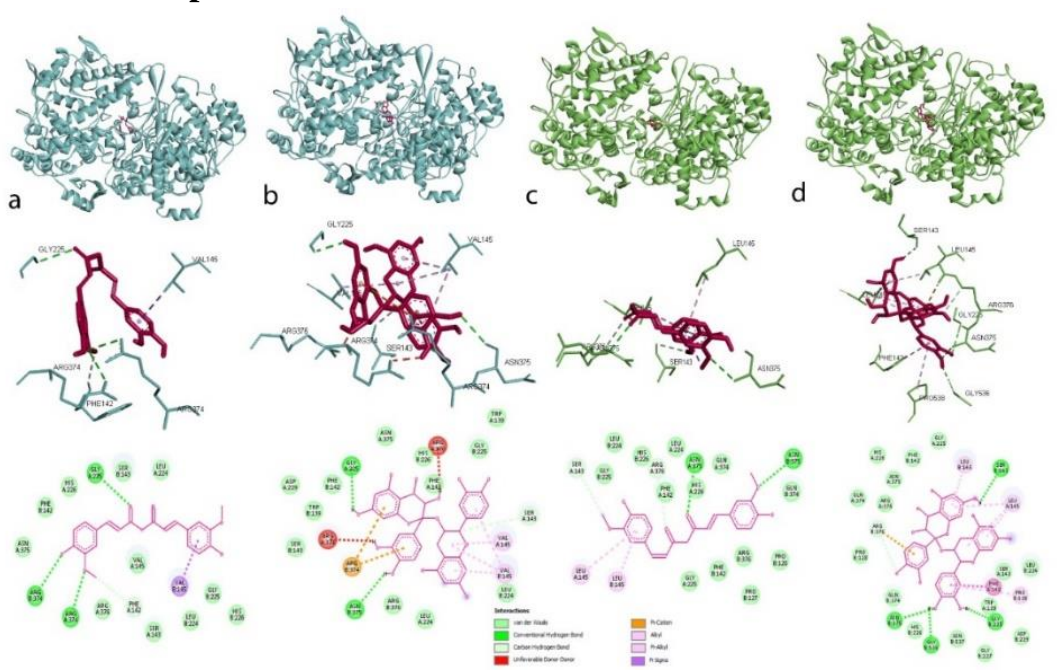

Figure 1. Interaction of Cyclooxygenases (COX-1 and COX-2) to Curcumin and Procyanidin: (a) COX-1 with Curcumin; (b) COX-1 with Procyanidin; (c) COX-2 with Curcumin; (d) COX-2 with Procyanidin. 


\subsection{Complex Compound (Curcumin-Procyanidin) Interaction to COXs Protein.}

In the complex form, procyanidin-curcumin form a complex that interact in the specific binding site and predicted able to inhibit COXs. Based on the result, the curcumin-procyanidin complex had specificity in binding with COXs. Both compounds bind to the specific site in the COXs, suggested that those sites are specific of curcumin-procyanidin binding. The complex also consists of two compounds, which suggested improve the binding stabilization. In contrast, the binding affinity of two complex compounds is lower than a single compound (Figure 2). The binding affinity of COX-1 to curcumin and procyanidin are $-7.6 \mathrm{kcal} / \mathrm{mol}$ and -10.0 $\mathrm{kcal} / \mathrm{mol}$, respectively. While binding of the curcumin-procyanidin complex to COX-1 is -3.5 $\mathrm{kcal} / \mathrm{mol}$, it also shows the same case in COX-2 binding. The binding affinity of COX-2 with curcumin and procyanidin is $-7.7 \mathrm{kcal} / \mathrm{mol}$ and $-9.7 \mathrm{kcal} / \mathrm{mol}$, respectively. However, it needs $-3.8 \mathrm{kcal} / \mathrm{mol}$ for the curcumin-procyanidin complex to bind with $\mathrm{COX}-2$. The smaller number of binding affinity indicates stronger interaction [33]. The binding affinity does not show a big difference, but the curcumin-procyanidin complex is more likely to bind to COX-2. The complex compound may restrain to each other and lead to reduced binding affinity.

From the visualization of complex binding, it suggested that complex compounds binding to COXs provide efficient inhibition. It blocks various sites and prevents the binding of natural arachidonic acid as the original substrate, leads to the reduction of prostaglandin synthesis. It proved that various binding sites showed by the analysis proved that crude material could be more effective than consuming individually. Strong and effective binding provided by each isolated compound interact with each other and posed a strong binding in complex compounds. Herbal plant complex compounds are a constituent that works synergistically with each other, thus improve the potential and safety than a single isolated compound [34-37]. A combination of phytochemical components performs a synergic mechanism resulting in the improvement of its biological activities in the body system [38-40]. This study indicates that menstrual pain could effectively reduce by tamarind-turmeric treatment.
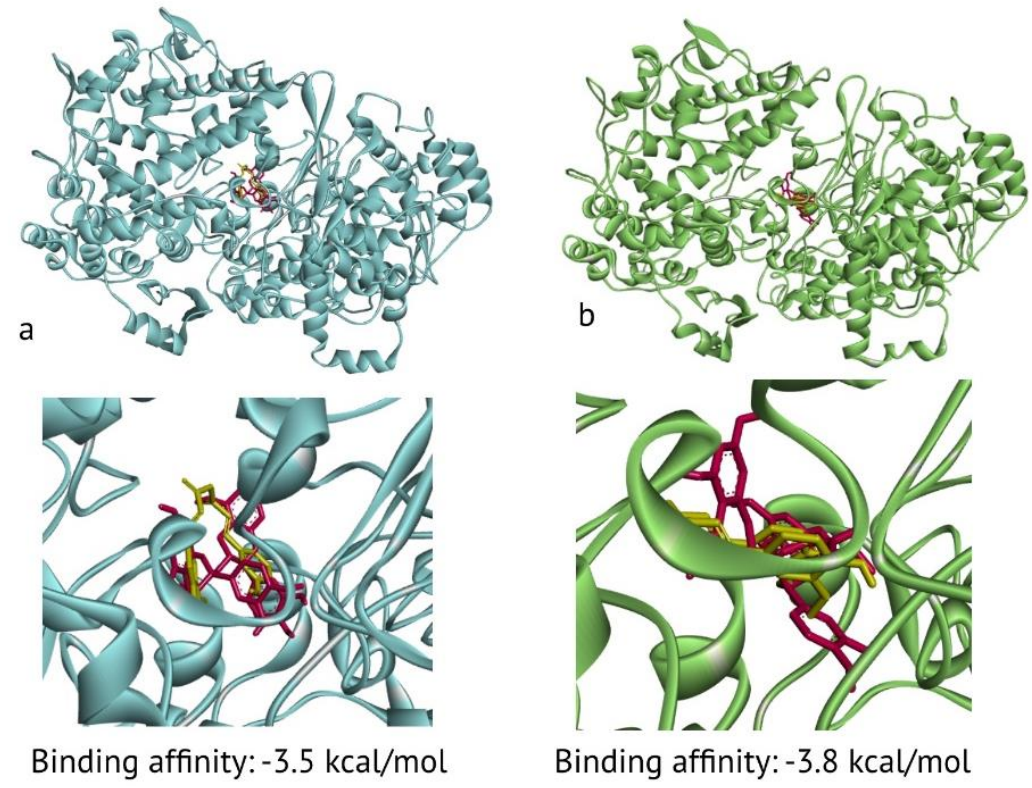

Figure 2. Complex binding of Curcumin with Procyanidin to COXs: (a) Curcumin-Procyanidin to COX-1; (b) Curcumin-Procyanidin to COX-2

The clinical study of the turmeric-tamarind product showed the effectiveness of the product in reducing knee pain. It is able to improve the musculoskeletal function by reducing 
inflammation. The product work by inhibit TNF $\alpha$ production and downregulate key inflammatory pain modulators; one of them is PGE2. It also showed the antioxidant activity by inhibiting NADPH oxidase activities [3,41]. Assessment of turmeric and tamarind drink effect on postpartum mothers showed a significant effect on the duration of perineal wound healing. The study suggested that anti-inflammatory, antioxidant, and anti-infectious activity of turmeric and tamarind contribute to wound healing [18]. Thus, the administration as a mixture will improve biological activity.

\section{Conclusions}

In conclusion, tamarind and turmeric bioactive compounds have potency as a natural therapy for primary dysmenorrhea. In silico study proved that complex form of bioactive compounds could stabilize protein-ligand binding and have high binding affinity in inhibiting COXs. This study needs further investigation through toxicology and/or pre-clinical study of complex ginger bioactive compounds.

\section{Funding}

This research received no external funding.

\section{Acknowledgments}

The authors acknowledged Richie Richardus Tokan for lab assistance and software installation.

\section{Conflicts of Interest}

The authors declare no conflict of interest.

\section{References}

1. Ashraf, K.; Sultan, S.A. Comprehensive Review on Curcuma longa Linn.: Phytochemical, Pharmacological, and Molecular Study. Int J Green Pharm 2017, 11, S671-85.

2. Komakech, R.; Kim, Y.G.; Matsabisa, G.M.; Kang, Y. Anti-inflammatory and analgesic potential of Tamarindus indica Linn. (Fabaceae): a narrative review. Integrative Medicine Research 2019, 8, 181-186, https://doi.org/10.1016/j.imr.2019.07.002.

3. Rao, P.S.; Ramanjaneyulu, Y.S.; Prisk, V.R.; Schurgers, L.J. A Combination of Tamarindus indica Seeds and Curcuma longa Rhizome Extracts Improves Knee Joint Function and Alleviates Pain in Non-arthritic Adults Following Physical Activity. Int J Med Sci 2019, 16, 845-53, https://doi.org/10.7150/ijms.32505.

4. Shirahigue, L.D.; Ceccato-Antonini, S.R. Agro-industrial wastes as sources of bioactive compounds for food and fermentation industries. Cienc Rural 2020, 50, 1-17, https://doi.org/10.1590/0103-8478cr20190857.

5. Efferth, T.; Koch, E. Complex Interactions between Phytochemicals. The Multi-Target Therapeutic Concept of Phytotherapy. Curr Drug Targets 2010, 12, 122-32, https://doi.org/10.2174/138945011793591626.

6. Primiani, C.N.; Lestari, U.; Amin, M.; Sumitro, S.B. Comparative study of effects daidzein contained in yam tuber Pachyrhizus erosus and pure daidzein: the dynamics of chemical compounds and its potential in myometrium. J Biol Res 2014, 18, 1-7.

7. Sahoo, N.; Manchikanti, P.; Dey, S. Herbal drugs: Standards and regulation. Fitoterapia 2010, 81, 462-71, http://dx.doi.org/10.1016/j.fitote.2010.02.001,

8. Shahrajabian, M.H.; Sun, W.; Cheng, Q. Clinical aspects and health benefits of ginger (Zingiber officinale) in both traditional Chinese medicine and modern industry. Acta Agric Scand Sect B Soil Plant Sci 2019, 69, 546-56, https://doi.org/10.1080/09064710.2019.1606930.

9. Welz, A.N.; Emberger-Klein, A.; Menrad, K. Why people use herbal medicine: Insights from a focus-group study in Germany. BMC Complement Altern Med 2018, 18,1-9, http://doi.org/10.1186/s12906-018-2160-6.

10. Sales, K.; Jabbour, H. Cyclooxygenase enzymes and prostaglandins in pathology of the endometrium. Reproduction 2003, 1, 559-67, https://doi.org/10.1530/rep.0.1260559.

11. Söderman L.; Edlund M.; Marions L. Prevalence and impact of dysmenorrhea in Swedish adolescents. Acta Obstet Gynecol Scand 2019, 98, 215-21, https://doi.org/10.1111/aogs.13480. 
12. Lai, Z.Z.; Yang, H.L.; Ha, S.Y.; Chang, K.K.; Mei, J.; Zhou, W.J.; Qiu, X.M.; Wang, X.Q.; Zhu, R.; Li, D.J.; Li, M.Q. Cyclooxygenase-2 in Endometriosis. International Journal of Biological Sciences 2019, 15, 2783-2797, https://doi.org/10.7150/ijbs.35128.

13. Barcikowska, Z.; Rajkowska-Labon, E, Grzybowska, M.E.; Hansdorfer-Korzon, R.; Zorena, K. Inflammatory markers in dysmenorrhea and therapeutic options. Int J Environ Res Public Health 2020, 17, 1-14, https://doi.org/10.3390/ijerph17041191.

14. Ricciotti, E.; FitzGerald, G.A. Prostaglandins and Inflammation. Arterioscler Thromb Vasc Biol 2011, 31 , 986-1000, https://doi.org/10.1161/ATVBAHA.110.207449.

15. Smyth, E.M.; Grosser, T.; Wang, M.; Yu, Y.; FitzGerald, G.A. Prostanoids in health and disease. J Lipid Res 2009, 50, S423-8, https://doi.org/10.1194/jlr.R800094-JLR200.

16. Setiawan, A.; Yin, L.; Auer, G.; Czene, K.; Smedby, K.E.; Pawitan, Y. Patterns of acute inflammatory symptoms prior to cancer diagnosis. Sci Rep 2017, 7, 1-5, http://dx.doi.org/10.1038/s41598-017-00133-8.

17. Asif, M. Chemistry and antioxidant activity of plants containing some phenolic compounds. Chem Internatioanl 2015, 1, 35-52, http://doi.org/10.6084/m9.figshare.7253357.v1.

18. Susanti, D.; Setiani, O.; Umaroh, U.; Aristiati, K.; Mashoedi, I.D.; Mardiyono, M. Effect of Consuming Tamarind and Turmeric Drink on the Length of Perineal Wound Healing in Postpartum Mothers. Belitung Nurs J 2017, 3, 399-404, https://doi.org/10.33546/bnj.155.

19. Sudjaroen, Y.; Haubner, R.; Würtele, G.; Hull, W.E.; Erben, G.; Spiegelhalder, B.; Changbumrung, S.; Bartsch, H.; Owen, R.W. Isolation and structure elucidation of phenolic antioxidants from Tamarind (Tamarindus indica L.) seeds and pericarp. Food and Chemical Toxicology 2005, 43, 1673-1682, https://doi.org/10.1016/j.fct.2005.05.013.

20. Terra, X.; Montagut, G.; Bustos, M.; Llopiz, N.; Ardèvol, A.; Bladé, C.; Fernández-Larrea, J.; Pujadas, G.; Salvadó, J.; Arola, L.; Blay, M. Grape-seed procyanidins prevent low-grade inflammation by modulating cytokine expression in rats fed a high-fat diet. The Journal of Nutritional Biochemistry 2009, 20, 210-218, http://dx.doi.org/10.1016/j.jnutbio.2008.02.005.

21. Rana, M.; Sharma, P.; Mahima, R.C.; Sharma, P. Proximate and phytochemical screening of the seed and pulp of Tamarind indica. J Med Plants Stud 2018, 6, 111-5.

22. Arshad, M.S.; Imran, M.; Ahmed, A.; Sohaib, M.; Ullah, A.; Nisa, Mun.; Hina, G.; Khalid, W.; Rehana, H. Tamarind: A diet-based strategy against lifestyle maladies. Food Sci Nutr 2019, 7, 3378-90, https://doi.org/10.1002/fsn3.1218.

23. Nelson, K.M.; Dahlin, J.L.; Bisson, J.; Graham, J.; Pauli, G.F.; Walters, M.A. The Essential Medicinal Chemistry of Curcumin. Journal of Medicinal Chemistry 2017, 60, 1620-1637, https://doi.org/10.1021/acs.jmedchem.6b00975.

24. Verma, M.K.; Najar, I.A.; Tikoo, M.K.; Singh, G.; Gupta, D.K.; Anand, R.; Khajuria, R.K.; Sharma, S.C.; Johri, R.K. Development of a validated UPLC-qTOF-MS Method for the determination of curcuminoids and their pharmacokinetic study in mice. DARU Journal of Pharmaceutical Sciences 2013, 21, 1-9, https://doi.org/10.1186/2008-2231-21-11.

25. Cas, M.D.; Ghidoni ,R. Dietary curcumin: Correlation between bioavailability and health potential. Nutrients 2019, 11, 1-14, https://doi.org/10.3390/nu11092147.

26. Rasoanaivo, P.; Wright, C.W.; Willcox, M.L.; Gilbert, B. Whole plant extracts versus single compounds for the treatment of malaria: Synergy and positive interactions. Malar $J$ 2011, 10, 1-12, https://doi.org/10.1186/1475-2875-10-S1-S4.

27. Rudyatmi, E.; Bintari, S.H.; Iswari, R.S. Feasibility study and sensory test of turmeric tamarind traditional drink with various processing. J Phys Conf Ser. 2018, 983, 1-6, https://doi.org/10.1088/17426596/983/1/012187.

28. Rouzer, C.A.; Marnett, L.J. Cyclooxygenases: structural and functional insights. Journal of Lipid Research 2009, S29-34, https://doi.org/10.1194/jlr.r800042-jlr200.

29. Ferreira De Freitas, R.; Schapira, M. A systematic analysis of atomic protein-ligand interactions in the PDB. Medchemcomm 2017, 8, 1970-81, http://dx.doi.org/10.1039/C7MD00381A.

30. Marcou, G.; Rognan, D. Optimizing fragment and scaffold docking by use of molecular interaction fingerprints. J Chem Inf Model 2007, 47, 195-207, https://doi.org/10.1021/ci600342e.

31. Bare, Y.; Krisnamurti, G.C.; Elizabeth, A.; Rachmad, Y.T.; Sari, D.R.T.; Lorenza, M.R.W.G. The potential role of caffeic acid in coffee as cyclooxygenase-2 (COX-2) inhibitor: in silico study. Biointerface Res. Appl. Chem 2019, 9, 4424-4427, https://doi.org/10.33263/BRIAC95.424427.

32. Novoseletsky, V.N.; Pyrkov, T.V.; Efremov, R.G. Analysis of hydrophobic interactions of antagonists with the beta2-adrenergic receptor. SAR QSAR Environ Res 2010, 21, 37-55, https://doi.org/10.1080/10629360903560637.

33. Arba, M.; Arfan, A.; Nuralifah; Haerunnisah, W.O.; Kadidae, L. In silico exploration for aldose reductation (AR) inhibitors. Lett. Appl. NanoBioScience 2020, 9, 956-960, https://doi.org/10.33263/LIANBS92.956960.

34. Bare, Y.; Sari, D.R.T.; Rachmad, Y.T.; Krisnamurti, G.C.; Elizabeth, A. In Silico Insight the Prediction of Chlorogenic Acid in Coffee through Cyclooxygenase-2 (COX2) Interaction. Biog J Ilm Biol 2019, 7, 1005, https://doi.org/10.24252/bio.v7i2.9847. 
35. Bernardini, S.; Tiezzi, A.; Laghezza, M.V.; Ovidi, E. Natural products for human health: an historical overview of the drug discovery approaches. Nat Prod Res 2018, 32, 1926-50, https://doi.org/10.1080/14786419.2017.1356838.

36. Choudhury, H.; Pandey, M.; Hua, C.K.; Mun, C.S.; Jing, J.K.; Kong, L.; Ern, L.Y.; Ashraf, N.A.; Kit, S.W.; Yee, T.S.; Pichika, M.R.; Gorain, B.; Kesharwani, P. An update on natural compounds in the remedy of diabetes mellitus: A systematic review. Journal of Traditional and Complementary Medicine 2018, 8, 361376, https://doi.org/10.1016/j.jtcme.2017.08.012.

37. Zhao, Q.; Luan, X.; Zheng, M.; Tian, X.H.; Zhao, J.; Zhang, W.D.; Ma, B.L. Synergistic mechanisms of constituents in herbal extracts during intestinal absorption: Focus on natural occurring nanoparticles. Pharmaceutics 2020, 12, 1-19, https://doi.org/10.3390/pharmaceutics12020128.

38. Phan, M.A.T.; Paterson, J.; Bucknall, M.; Arcot, J. Interactions between phytochemicals from fruits and vegetables: Effects on bioactivities and bioavailability. Crit Rev Food Sci Nutr 2018, 58, 1310-29, https://doi.org/10.1080/10408398.2016.1254595.

39. Pezzani, R.; Salehi, B.; Vitalini, S.; Iriti, M.; Zuñiga, A.F.; Sharifi-Rad, J.; Martorell, M.; Martins, N. Synergistic Effects of Plant Derivatives and Conventional Chemotherapeutic Agents: An Update on the Cancer Perspective. Medicina 2019, 55, 1-16, https://doi.org/10.3390/medicina55040110.

40. Arun, K.B.; Dhanya, R.; Chandran, J.; Abraham, B.; Satyan, S.; Nisha, P. A comparative study to elucidate the biological activities of crude extracts from rice bran and wheat bran in cell line models. J Food Sci Technol 2020, https://doi.org/10.1007/s13197-020-04353-1.

41. Bagul, M.B.; Sonawane, S.K.; Arya, S.S. Bioactive characteristics and optimization of tamarind seed protein hydrolysate for antioxidant-rich food formulations. 3 Biotech 2018, 8, 1-8, https://doi.org/10.1007/s13205018-1240-0. 